\title{
Controlled Polymerization by Incarceration of Monomers in Nanochannels
}

$\operatorname{AUTHOR}(\mathrm{S})$ :

Uemura, Takashi; Kitagawa, Susumu

CITATION:

Uemura, Takashi ...[et al]. Controlled Polymerization by Incarceration of Monomers in Nanochannels. Topics in Current Chemistry 2010, 293: 155-173

ISSUE DATE:

2010

URL:

http://hdl.handle.net/2433/130697

\section{RIGHT:}

The original publication is available at www.springerlink.com; This is not the published version. Please cite only the published version.; この 論文は出版社版でありません。引用の際には出版社版をご確認ご利用 ください。 


\title{
Controlled Polymerization by Incarceration of Monomers in Nanochannels
}

\author{
Takashi Uemura ${ }^{1}$ and Susumu Kitagawa ${ }^{1,2}$ \\ ${ }^{1}$ Department of Synthetic Chemistry and Biological Chemistry, Graduate School \\ of Engineering, Kyoto University, Katsura, Nishikyo-ku, Kyoto 615-8510, Japan \\ 2 Institute for Integrated Cell-Material Science (iCeMS), Kyoto University, \\ Yoshida, Sakyo-ku, Kyoto 606-8501, Japan \\ E-mail: uemura@sbchem.kyoto-u.ac.jp, kitagawa@sbchem.kyoto-u.ac.jp
}

Table of Contents:

1. Introduction

2. Design of Host Frameworks

2.1 Regularity

2.2 Pore Size and Shape

2.3 Pore Surface Functionality

2.4 Host Flexibility

3. Inclusion Polymerizations

3.1 Radical Polymerization

3.2 Catalytic Polymerization

4. Control of Polymer Structures

4.1 Stereoregularity

4.2 Topology

4.3 Molecular Weight

5. Conclusion and Perspectives

\begin{abstract}
:
Recently, Metal-Organic Frameworks (MOFs) or Porous Coordination Polymers (PCPs) composed of transition metal ions and bridging organic ligands have been extensively studied. The characteristic features of PCPs are highly regular channel structures, controllable channel sizes approximating molecular dimensions, designable surface potentials and functionality, and flexible frameworks responsive to guest molecules. Owing to these advantages, successful applications of PCPs range from
\end{abstract}


molecular storage/separation to heterogeneous catalysts. In particular, use of their regulated and tunable nanochannels for a field of polymerization has allowed multi-level controls of polymerization (controls of stereoregularlity, molecular weight, etc.). In this chapter, we focuses on recent progress in polymerization utilizing the nanochannels of PCPs, and demonstrates why this polymerization system is attractive and promising, from the viewpoints of precision controls of polymer structures.

Keywords:

Polymerization, PCP, Nanochannel, Polymer Structure,

$\begin{array}{ll}\text { Abbreviations: } & \\ \text { adc } & 9,10 \text {-anthracenedicarboxylate } \\ \text { bdc } & 1,4 \text {-benzenedicarboxylate } \\ \text { bpd } & \text { biphenyl-4,4'-dicarboxylate } \\ \text { bpy } & 4,4 \text { '-bipyridine } \\ \text { DVB } & \text { divinylbenzene } \\ \text { gel permeation chromatography GPC } \\ \text { MMA } & \text { methyl methacrylate } \\ \text { MOF } & \text { Metal-Organic Framework } \\ M_{\mathrm{n}} & \text { number-average molecular weight } \\ M_{\mathrm{w}} & \text { weight-average molecular weight } \\ \text { ndc } & 1,4-\text {-naphthalenedicarboxylate } \\ \text { PCP } & \text { Porous Coordination Polymer } \\ \text { pzdc } & \text { pyrazine-2,3-dicarboxylate } \\ \text { PMMA } & \text { poly(methyl methacrylate) } \\ \text { PSt } & \text { polystyrene } \\ \text { PVAc } & \text { poly(vinyl acetate) } \\ \text { St } & \text { styrene } \\ \text { ted } & \text { triethylenediamine } \\ \text { VAc } & \text { vinyl acetate }\end{array}$

\section{Introduction}

All naturally occurring polymers are produced by enzymatic catalysis, where stereoselective, regioselective, and chemoselective polymerizations proceed effectively within regulated and well-organized molecular-scale spaces. Inspired by the elegant operations in these biological events, many synthetic chemists have focused their research 
interests on polymer synthesis in confined and designed nanospaces to attain precise structural controls of artificial polymers [1-8]. In particular, microporous materials (pore size $<2 \mathrm{~nm}$ ) with regular channel structures, such as porous organic crystals and zeolites, have imposed specific size and shape effects of the nanochannels on the reaction kinetics and selectivity in the solid-state inclusion polymerization processes. For example, extensive studies on polymerization in the organic hosts have been made from the 1960s-80s, focusing on radical polymerization of conjugated diene and triene monomers irradiated with $\gamma$-rays [9-18]. Highly stereoregular and sometimes optically active chiral polymers were obtained in the inclusion polymerizations utilizing the organic hosts. On the other hand, impregnation of transition metal ions, such as $\mathrm{Cu}(\mathrm{II})$, $\mathrm{Fe}(\mathrm{III}), \mathrm{Ni}(\mathrm{II})$, and $\mathrm{Co}(\mathrm{II})$, into the nanochannels of microporous zeolites is effective for oxidative polymerizations to produce many conjugated (semi)conducting polymers [1923]. Mesoporous materials (pore size $>2 \mathrm{~nm}$ ) are also attractive from the viewpoints of polymerization as well as fabrications of nanocomposite materials [24-29].

Since the early 1990s, the quest for MOFs or PCPs composed of transition metal ions and bridging organic ligands has been the subject of intense research because of their potential applications in many areas, including molecular storage, separation, and exchange [30-37]. Much research effort has been devoted to developing characteristic features of PCPs that differ from those of conventional microporous materials, such as organic hosts, zeolites and activated carbons: 1) highly regular channel structures, 2) controllable channel size approximating molecular dimensions, 3) designable surface potentials and functionality, and 4) flexible frameworks responsive to guest molecules. These features are of key importance for the creation of unique nanosize reaction fields based on the PCP materials. Thus, control of molecular reaction and transformation within the confined environments utilizing the functional channels of PCPs is currently an important topic in this area, prompting vigorous efforts in the development of PCPs for applications in heterogeneous catalysis, asymmetric reaction, and ship-in-bottle synthesis [38-47]. In particular, employing the PCP nanochannels as a field of polymerization is an attractive idea, which would allow multi-level controls of polymerization (controls of stereo- and regioregularity, molecular weight, polymer topology, etc.) by efficient through-space inductions and specific host-monomer interactions [48]. Because of the highly designable features of PCPs, these functional nanochannels can be applied to a tailor-made polymerization system to obtain preferred polymer structures; such a system is nano-information transcription polymerization.

In this chapter, we will describe how the host frameworks based on PCPs can be designed for the fields of polymerizations in the first section. Then, in the following section, details of inclusion polymerization in PCPs, such as radical and catalytic 
polymerization processes, are considered. Finally, in the next section, the significant effects of host framework structures on polymer primary structure are discussed.

\section{Design of Host Frameworks}

\subsection{Regularity}

Regular nanosize pores are suitable to confine guest molecules even when the intermolecular interaction between guest and host molecules is governed only by the dispersion force, the so-called van der Waals force. Self-assembly processes from building blocks of metal ions and organic ligands afford microprous structures of PCPs with their particle dimensions of approximately $1 \mu \mathrm{m}^{3}$. Considering that the cross sections of channels of PCPs are mostly ranged from 0.4 to $2.0 \mathrm{~nm}$, one can obtain several millions of regular channels in a particle with a size of $1 \mu \mathrm{m}^{3}$ [49]. Such regular channels, with their sharp distribution of pore size due to their high crystallinity, provide advantages for controlled polymerization. Densely adsorbed monomers inside the channels are favorable to high reactive/regulated polymerization because all of the channels can be utilized as a reaction field. If we prepare an assembled guest structure with one-directional orientation or hetero-guests accommodation (e.g., AAABBB, $\mathrm{AB} A B \mathrm{AB} \ldots$...) by employing specific regular micropores, we could achieve block or alternating copolymerization and sequence-controlled polymerization. By tuning the regularity of the potential field of the channels, we can create well-ordered monomer assemblies inside the PCP channels toward the target polymerization.

\subsection{Pore Size and Shape}

The reactivity of guest molecules in confined nanospaces is strongly dependent on the molecular states and behaviors. Generally, the pore sizes of PCPs range from 0.4 to $2.0 \mathrm{~nm}$ [49]. In addition, a variety of the pore shapes of PCPs, such as triangle, rectangle, and hexagonal shapes, has been prepared by the possible combinations of directional organic ligands and geometric metal inos. From the viewpoint of channel dimension, not only one-dimensional but also layered or 3D intersecting channel structures can be synthesized in the PCP materials [49-51]. By tuning these pore size and shape of PCPs, we can create a nanospace with strong confinement capability for a wide range of monomers from gas molecules (e.g., acetylene, ethylene) to larger molecules (e.g., MMA, St) even at room temperature. With the aid of this confinement, we can control the mobility, alignment, and density of adsorbed molecules in the pore, which is often advantageous for controlled polymerizations.

\subsection{Pore Surface Functionality}


If one can prepare PCP nanochannels with surface functional Lewis acidic or basic moiety [52], they will be applied to catalytic pores for a variety of polymerization reactions. In this regard, most PCPs have pore surfaces with coordinatively saturated functional groups. The introduction of Lewis-acidic sites into the pore, however, requires coordinatively unsaturated metal cation(s) (open metal site(s)) in the pore surface [36, 37, 53-55]. Taking into account that the coordinative saturation of metal ions in PCPs tends to occur in usual frameworks, a clue to create open metal sites is to use volatile solvent molecules bound to metal ions, such as a water molecule, functionalizing the surface towards guest molecules. The removal of the volatile molecules by heating under vacuum results in Lewis-acidic pore surfaces.

The basic functional sites contribute essentially to superior characteristics of metalorganic frameworks. In spite of their great importance, reports on PCPs with basic porous surfaces have been rare because basic groups are preferentially bound by metal ions as connectors during the assembly $[47,56,57]$. The most quoted examples of robust PCPs are constructed using transition metal cations with either an anionic multicarboxylate or a neutral bipyridyl linker, whose coordination sites are used to form available pore structures. On the other hand, the creation of free base-functionalized channels is a difficult target as the coordination strength of these ligands increases.

Introduction of relatively weak functional groups, such as carbonyl, hydroxyl, nitro, amide, etc., the nanochannels of PCPs would affect the monomer alignment, which may lead to precision controls of stereoselectivity and regioselectivity of the resulting polymers. In particular, the PCPs with either helical or chiral structures on the pore surface are of intense interest in chemistry and such porous solids are potentially useful to find applications in enantioselective sorption/separation and catalysis [35, 39, 40, 41, 43, 46]. Of considerable interest is the use of the chiral channels to affect asymmetric polymerizations such as asymmetric selective polymerization of racemic monomers as well as asymmetric polymerization of prochiral monomers, which may give helical polymer conformations.

\subsection{Host Flexibility}

Dynamic structural transformation based on flexible frameworks is one of the most interesting and presumably characteristic phenomena of PCPs, which cannot be attained by conventional microporous materials such as zeolites and activated carbons [58-62]. Creation of flexible host frameworks that interact with exchangeable guest species in a switchable fashion has implications for the generation of previously undeveloped advanced materials with applications in areas such as molecular sensing. From the viewpoint of inclusion polymerization, utilizations of such flexible frameworks based on PCPs would be key principles for highly selective recognition, alignment, and 
reaction of the accommodated monomers, which is similar to the induced fit theory illustrated by enzymes in biological systems.

The key to creating a flexible framework is to utilize weak molecular interactions in addition to the strong covalent and coordination bonds. Actually, coordination bonds in PCPs are frequently supported by hydrogen bonds, $\pi-\pi$ stacking, and van der Waals forces and other weak interactions. Intermolecular links with these weaker interactions produce flexible parts in a framework, so that the system can exist in two or more solid phases. Depending on the external perturbations and guest molecules, the system will be in one of the multiple solid phases.

\section{Inclusion Polymerizations}

\subsection{Radical Polymerization}

Radical polymerization is the most widely employed process for obtaining organic polymeric materials, not only in industry, but also in the laboratory, because of its versatility in polymerizing a variety of monomers $[63,64]$. The industrial significance of radical polymerization is evident in the fact that it accounts for about $50 \%$ of all commercial polymers. Recently, radical polymerization of various common vinyl monomers, such as St, MMA, and VAc, has been performed in the PCP nanochannels of $\left[\mathrm{M}_{2}(\mathrm{~L})_{2} \text { ted }\right]_{\mathrm{n}}\left(\mathrm{M}=\mathrm{Cu}^{2+}\right.$ or $\left.\mathrm{Zn}^{2+}\right)$ whose channel size can be systematically controlled from 4.3 to $10.8 \AA$ by change of bridging dicarboxylate ligands L (Fig. 1 and 2) [65, 66]. In the polymerization systems of St and MMA, a strong correlation between the pore size of the PCPs and polymer yield is clearly seen, where the conversions for polymerizations decrease as the size of the nanochannels narrows (Tables 1 and 2). No polymeric product was obtained during the polymerizations in the narrowest channels of $\left[\mathrm{Cu}_{2}(\mathrm{adc})_{2} \text { ted }\right]_{n}$ and $\left[\mathrm{Zn}_{2}(\mathrm{adc})_{2} \text { ted }\right]_{n}$ (pore size $=4.8 \times 4.3 \AA^{2}$ ). The solid-state NMR measurement has been used for explaining this pore-size-dependent polymerizability of the encapsulated monomers (Fig. 3). The line shapes of the ${ }^{2} \mathrm{H}$ NMR spectra for St- $d_{8}$ adsorbed in the larger nanochannels of $\left[\mathrm{Cu}_{2}(\mathrm{bpd})_{2} \text { ted }\right]_{n}$ (pore size $=10.8 \times 10.8 \AA^{2}$ ) and $\left[\mathrm{Cu}_{2}(\mathrm{bdc})_{2} \text { ted }\right]_{n}$ (pore size $=7.5 \times 7.5 \AA^{2}$ ), revealed that the guest St has high mobility with fast rotation in the nanochannels. In contrast, the spectrum for St- $d_{8}$ in $\left[\mathrm{Cu}_{2}(\mathrm{adc})_{2} \text { ted }\right]_{n}$ showed completely solid-like behavior, even at the polymerization temperature, indicating that the mobility of St in this narrow channel was highly restricted. This restricted arrangement of the $\mathrm{St}$ in the nanochannel resulted in the poor reactivity of St. Compared with the polymerizations of St and MMA, the polymer yields in VAc system were relatively low (Table 3); in particular, no trace of polymeric product was observed in the polymerizations utilizing even the nanochannels of $\left[\mathrm{M}_{2}(\mathrm{ndc})_{2} \text { ted }\right]_{n}$ (pore size $=5.7 \times 5.7 \AA^{2}$ ). This inhibited conversion of VAc in the 
nanochannels was ascribed to its low reactivity towards carbon radicals derived from an initiator, due to the lack of a conjugated substituent in the VAc monomer unlike St and MMA.

It was reported that the framework flexibility of PCPs is also a key importance to polymerizability of included monomers [67]. The polymerization of 1,4-disubstituited DVB ( $p$-DVB; molecular dimension $=8.5 \times 4.4 \AA$ ) was carried out in the nanochannels of $\left[\mathrm{Zn}_{2}(\mathrm{bdc})_{2} \text { ted }\right]_{n}$ and an isostructural copper complex $\left[\mathrm{Cu}_{2}(\mathrm{bdc})_{2} \mathrm{ted}\right]_{n}$ under the same conditions. In this experiment, polymeric product was obtained in the nanochannels of the $\mathrm{Zn}$ compound, in contrast, no trace of polymer was observed by using the $\mathrm{Cu}$ complex. In addition, the thermogravimetric analysis showed that the adsorbed amount of the monomer in $\left[\mathrm{Zn}_{2}(\mathrm{bdc})_{2} \mathrm{ted}\right]_{n}$ was much larger than that in $\left[\mathrm{Cu}_{2}(\mathrm{bdc})_{2} \mathrm{ted}\right]_{n}$. The XRPD measurements gave an important clue to the different adsorption/polymerization properties of $\left[\mathrm{M}_{2}(\mathrm{bdc})_{2} \text { ted }\right]_{n}$ (Fig. 4). In the series of XRPD patterns, small changes of peak positions were observed after the introduction of $p$-DVB in $\left[\mathrm{Zn}_{2}(\mathrm{bdc})_{2} \mathrm{ted}\right]_{n}$, however, the framework of $\left[\mathrm{Cu}_{2}(\mathrm{bdc})_{2} \text { ted }\right]_{n}$ never showed such structural changes. The detailed framework change of $\left[\mathrm{Zn}_{2}(\mathrm{bdc})_{2} \text { ted }\right]_{n}$ was examined by using synchrotron XRPD, showing that introduction of $p$-DVB in the channel induces certain lattice expansion compared with the original host. From these data, averaged distances between $p$-DVB in the channels of $\left[\mathrm{Zn}_{2}(\mathrm{bdc})_{2} \text { ted }\right]_{n}$ and $\left[\mathrm{Cu}_{2}(\mathrm{bdc})_{2} \text { ted }\right]_{n}$ could be estimated to be 4.5 and $10.6 \AA$, respectively, suggesting a polymerizable closed packing structure of $p$-DVB in the channel of $\left[\mathrm{Zn}_{2}(\mathrm{bdc})_{2} \mathrm{ted}\right]_{n}$.

Thus, the pore size, shape, and flexibility of PCPs strongly affect the dynamics and arrangement of the included monomers, and the behavior of the monomers is a key factor in promoting polymerization in the porous frameworks.

\subsection{Catalytic Polymerization}

It was demonstrated that surface basic site of a PCP successfully catalyzed a polymerization in the nanochannels: the pillared-layer complex $\left[\mathrm{Cu}_{2}(\mathrm{pzdc})_{2} \mathrm{bpy}\right]_{n}$ proceeded a spontaneous polymerization of substituted acetylenes in a specific manner (Fig. 5) [68]. In the case of acidic monosubstituted acetylenes, the basic oxygen atoms from carboxylate ligands in $\left[\mathrm{Cu}_{2}(\mathrm{pzdc})_{2} \mathrm{bpy}\right]_{n}$ produced reactive acetylide species that subsequently initiated anionic polymerization in the nanochannel. Compared with a controlled experiment using a discrete model catalyst (sodium benzoate), this polymerization system exhibited drastic acceleration of the polymerization. For example, the reaction of methyl propiolate with the model catalyst at room temperature for one month gave only a trace amount of product. Increase in the reaction temperature to $70{ }^{\circ} \mathrm{C}$ was also ineffective for the polymerization. However, the reaction of the 
acetylene monomer with $\left[\mathrm{Cu}_{2}(\mathrm{pzdc})_{2} \mathrm{bpy}\right]_{n}$ for $12 \mathrm{~h}$ at room temperature successfully provided the polymeric product. This unique catalytic polymerization mechanism in $\left[\mathrm{Cu}_{2}(\mathrm{pzdc})_{2} \mathrm{bpy}\right]_{n}$ was supported by IR measurement and computer simulation using a universal force field. The experiments with various combinations of acetylene monomers and host PCPs showed that appropriate channel size, as well as the basic carboxylate moiety, is important for this spontaneous polymerization.

\section{Control of Polymer Structures}

\subsection{Stereoregularity}

One of the most important subjects in the field of polymer synthesis is stereocontrolled polymerizations. In particular, structural control of vinyl polymers to fabricate the desired stereoregularity (tacticity) is highly important, because the tacticity of the polymers strongly affects the properties of polymers. Therefore several research groups have intensively studied the control of the tacticity of vinyl polymers during solution radical polymerizations [69-74]. In these systems, the addition of fluoroalcohols or Lewis acids to the reaction media could lead to hydrogen bonding or coordinative interaction of the solvents or the additives with the polar groups in the monomers and/or the growing species, which caused stereospecific chain growth. However, this method can only be applied to monomers with the carbonyl group, and it is still uncertain whether steric or electronic interaction works on the stereostructures. Recently, stereocontrolled radical polymerization of vinyl monomers (St, MMA, and VAc) has been attained in nanochannels of $\left[\mathrm{M}_{2}(\mathrm{~L})_{2} \text { ted }\right]_{\mathrm{n}}\left(\mathrm{M}=\mathrm{Cu}^{2+}\right.$ or $\left.\mathrm{Zn}^{2+}\right)$, which led to an increase in isotacticity in the resulting polymers [66]. For example, the tacticity of PMMA strongly depends on the pore size of the PCPs; eventually an increase of $9 \%$ in isotacticity was achieved by using $\left[\mathrm{Cu}_{2}(\mathrm{ndc})_{2} \text { ted }\right]_{n}$ compared with that obtained from the bulk polymerization system (Table 2 and Fig. 6). When the VAc monomer was polymerized in the nanochannels of $\left[\mathrm{Zn}_{2}(\mathrm{bdc})_{2} \text { ted }\right]_{n}$, the ratio of isotactic units in the PVAc structure clearly increased (8\%) (Table 3). Because there is no specific interaction between the adsorbed monomers and the pore walls, effective through-space interactions by the nanochannels of the PCPs successfully induced the polymerizations with less stereo-bulky isotactic units. Thus, in this polymerization system, the nanochannel size effect on the tacticity of the vinyl polymers could be systematically studied, showing that controlled increase of isotacticity became possible in the polymerizations utilizing the size-tunable pores of PCPs.

Much effort has also been devoted to stereocontrolled polymerization of the substituted acetylene monomers, because stereoregularity (cis and trans chain sequence) of resulting polyacetylenes affects their characteristic properties, such as conjugation length, conductivity, suprastructures, and processability [75-78]. A remarkably high 
stereoselectivity was achieved by the polymerization of substituted acetylenes in the nanochannels of $\left[\mathrm{Cu}_{2}(\mathrm{pzdc})_{2} \text { bpy }\right]_{n}$ (Fig. 7), determined by IR and UV-vis spectroscopies [68]. The narrow nanochannel structure could successfully direct the polymerization with trans-geometric addition, which strikingly contrasts with the result obtained by using a model catalyst (sodium benzoate) where only unfavorable cyclic byproducts (trisubstituted benzenes) and a cis-geometric polymer were obtained in very low yields.

\subsection{Suppression of Cross-linking}

The advent of efficient methods for controlling or suppressing cross-linking structures in polymerization reaction is required for the further development of functional polymer materials. For example, linear polymers bearing pendant vinyl groups in the backbones are attractive from the viewpoints of potential reactivity of the olefinic double bonds and application as polymer precursors [79, 80]. Usually, radical polymerization of DVBs in bulk or solutions results in formation of hyper-branched network polymers, because the reactivity of the two vinyl moieties in DVBs is equivalent. However, a radical polymerization of DVBs in one-dimensional channels of $\left[\mathrm{M}_{2}(\mathrm{bdc})_{2} \text { ted }\right]_{n}$ gave a linear polymer remaining pendant vinyl groups in all benzene rings, which was confirmed by solubility check and spectroscopic measurements, such as IR, UV-vis, and ${ }^{1} \mathrm{H}$ NMR spectra [67]. For example, poly $\left(p\right.$-DVB) obtained from $\left[\mathrm{Zn}_{2}(\mathrm{bdc})_{2} \mathrm{ted}\right]_{n}$ was soluble in various organic solvents, such as THF, $\mathrm{CHCl}_{3}$, DMF, DMSO, etc., which highly contrasts with an insoluble product from the usual radical polymerization of DVBs in solution and bulk. In the ${ }^{1} \mathrm{H}$ NMR spectrum of the polymer, peaks assignable to the $\beta$-carbon of vinyl groups in the polymer structure were found at 5.1 and $5.7 \mathrm{ppm}$. Comparison of the peak integrations between the aromatic and the vinyl regions clearly shows that only one vinyl group of $p$-DVB was selectively polymerized to form the linear polymer, and unfavorable kink structures (branching and/or bonding through both 1,4-vinyl group) hardly formed during the reaction (Fig. 8). Thus, it is of considerable interest that the functional PCPs successfully directed the linearly extended polymerization of multivinyl monomers because of effective entrapments of the reactive propagating radical mediators in the one-dimensional nanochannels. To elucidate an importance of the channel size for this topotactic polymerization, polymerization of $p$-DVB in the framework of $\left[\mathrm{Cu}_{2}(\mathrm{bpd})_{2}(\text { ted })\right]_{\mathrm{n}}$ with large open channels (pore size $=10.8 \times 10.8 \AA^{2}$ ) was studied. In this case, the polymerization of $p$-DVB proceeded in high conversion $(63 \%)$; however, the obtained polymeric product isolated from the channels was insoluble in any solvents, showing that semi-branching cross-linked structures was formed in this large channel. This fact suggests that design of channel size suitable for single molecular accommodation of $p$-DVB is also a key factor to the selective linear polymerization. 
Owing to the nonconjugated nature of the propagating radical of PVAc, unfavorable chain transfer and termination reactions are particularly observed in the radical polymerization process of VAc, thus, the resultant PVAc usually has many branching structures. It is noteworthy that branching formations of PVAc were effectively suppressed during the polymerization in the nanochannels of PCPs [66]. The absolute value of the weight-average molecular weight of PVAc prepared in $\left[\mathrm{Cu}_{2}(\mathrm{bdc})_{2} \text { ted }\right]_{n}$, determined by multiangle laser light scattering coupled with GPC, was fairly consistent with that obtained from a conventional GPC measurement using the same column. This fact clearly supports the less-branching linear structure of the obtained PVAc due to the constrained chain growth in the narrow one-dimensional nanochannel of $\left[\mathrm{Cu}_{2}(\mathrm{bdc})_{2} \text { ted }\right]_{n}$.

\subsection{Molecular Weight}

To enhance and improve the properties of the polymeric materials, precision polymerization to control molecular weight and its polydispersity is particularly an important topic. However, in the radical polymerization process, the control of molecular weight is very difficult because of the fact that the high reactivity of growing radical species usually causes unfavorable termination and chain transfer reactions. Recently, living radical polymerization of vinyl monomers in solution systems has emerged as an effective method for precision vinyl polymer synthesis, because this polymerization is free from the side reactions resulting from the introduction of dormant species and can thus control the molecular weights [81-83].

It has been recently reported that, in the system of radical polymerizations of St and MMA utilizing the nanochannels of PCPs, the molecular weight distributions of the resultant polymers were found to become narrower with decrease in the host channel size, and eventually a value for $M_{\mathrm{w}} / M_{\mathrm{n}}$ of 1.5 was attained in the polymerization of St using $\left[\mathrm{Zn}_{2}(\mathrm{ndc})_{2} \mathrm{ted}\right]_{n}$ (Table 1 and 2) $[65,66]$. ESR measurements of propagating radicals in nonmagnetic hosts $\left[\mathrm{Zn}_{2}(\mathrm{bdc})_{2} \mathrm{ted}\right]_{n}$, examined during these polymerizations, showed intense signals assigned to the propagating radical of both PSt and PMMA in the ESR spectra (Fig. 9), and the maximum radical concentrations of PSt and PMMA in $\left[\mathrm{Zn}_{2}(\mathrm{bdc})_{2} \text { ted }\right]_{n}$ reached 2.6 and $0.48 \mathrm{mmol} \mathrm{kg}^{-1}$, respectively. These values are much higher than those detected in conventional solution radical polymerizations $\left(10^{-4}-10^{-5}\right.$ $\left.\mathrm{mmol} \mathrm{kg}{ }^{-1}\right)$. It is also observed that, after the polymerization of St in $\left[\mathrm{Zn}_{2}(\mathrm{bdc})_{2} \text { ted }\right]_{n}$, the ESR signal for the propagating radical still appears for three weeks, even at $70{ }^{\circ} \mathrm{C}$. Thus, in this polymerization system, PCPs with small pore sizes could significantly stabilize the propagating radicals by efficient suppression of termination reactions in the nanochannels, realizing living radical polymerizations with narrow polydispersity of molecular weight. 
Unlike St and MMA, the propagating radical of PVAc shows intractably high reactivity and less stability because of the lack of a conjugated substituent in the VAc monomer. Thus, achievement of a narrow molecular weight distribution of PVAc has still been limited, except for a few controlled living radical polymerization systems [8489]. However, PVAc obtained from the nanochannels of PCPs showed small $M_{\mathrm{w}} / M_{\mathrm{n}}$ values (e.g., $M_{\mathrm{w}} / M_{\mathrm{n}}$ of PVAc prepared in $\left[\mathrm{Cu}_{2}(\mathrm{bdc})_{2} \text { ted }\right]_{n}$ was 1.7$)$ in those GPC measurements, while PVAc prepared under the similar bulk conditions showed an extremely large polydispersity $\left(M_{\mathrm{w}} / M_{\mathrm{n}}>20\right)$ of the molecular weight caused by its hyperbranched structure derived from various side reactions (chain transfer and termination reactions) (Table 3 and Fig. 10) [66]. This is also the narrow nanochannel effect of PCPs on stabilization of the PVAc growing radical.

\section{Concluding Remarks}

The study on polymerization of monomers encapsulated in the channels of functional PCPs has provided significant opportunities for controlled polymerizations, such as stereoregularity, topology, and molecular weight of polymers. The capability for designable nanochannels of PCPs (regular channel structures, controllable channel size and surface functionality, and flexible frameworks) is one of the most powerful advantages of PCPs, which has led to the systematic studies of inclusion polymerizations in microporous channels based on PCPs. We believe that this polymerization system can provide a new aspect of controlled polymerizations, and is fundamentally important for the understanding of the role of pore size, geometry and flexibility in attaining tailormade polymerizations to obtain preferred polymer structures.

From the viewpoint of applications, further research could be also directed to the quest of polymer physics and properties in the nanochannels of PCPs, as well as construction of polymer-PCPs nanohybrids, so as to enhance the knowledge on applications to nanosize molecular-based devices.

\section{Acknowledgement}

We would like to thank all our collaborators and colleagues, whose names appear with ours in a number of references, for their contributions. We are also grateful for financial supports from JST-PRESTO program, a Grant-in-Aid for Scientific Research in a Priority Area "Chemistry of Coordination Space", and a Grant-in-Aid for Young Scientists (B) from the Ministry of Education, Culture, Sports, Science and Technology, Government of Japan. 


\section{References}

1. Paleos CM (ed) (1992) Polymerization in Organized Media. Gordon \& Breach, New York

2. Miyata M (1996) In: Reinhoudt D (ed) Comprehensive Supramolecular Chemistry, Vol. 10. Pergamon, Oxford p 557

3. Farina M, Di Silvestro G, Sozzani P (1996) In: Reinhoudt D (ed) Comprehensive Supramolecular Chemistry, Vol. 10. Pergamon, Oxford p 371

4. Moller K, Bein T (1998) Chem Mater 10:2950

5. Tajima K, Aida T (2000) Chem Commun 2399

6. Cardin DJ (2002) Adv Mater 14:553

7. Kobayashi S, Uyama H, Kimura S (2001) Chem Rev 101:3793

8. Serizawa T, Hamada KI, Akashi M (2004) Nature 429:52

9. White DM (1960) J Am Chem Soc 82:5678

10. Brown Jr. JF, White DM (1960) J Am Chem Soc 82:5671

11. Chatani Y, Nakatani S, Tadokoro H (1970) Macromolecules 3:481

12. Allcock HR, Silverberg EN, Dundley GK (1994) Macromolecules 27:1033

13. Allcock HR, Dudley GK, Silverberg EN (1994) Macromolecules 27:1039

14. Farina M, Audisio G, Natta G (1967) J Am Chem Soc 89:5071

15. Farina M, Audisio G Gramegna MT (1972) Macromolecules 5:617

16. Sozzani P, Di Silvestro G (1986) J Polym Sci Part A: Polym Chem 24:815

17. Miyata M, Morioka K, Takemoto K (1977) J Polym Sci Polym Chem Ed 15:2987

18. Miyata M, Kitahara Y, Osaki Y, Takemoto K (1984) J Inclusion Phenom 2:391

19. Cardin DJ (2002) Adv Mater 14:553

20. Bein T, Enzel P (1989) Angew Chem Int Ed 28:1629

21. Enzel P, Bein T (1989) J Phys Chem 93:6270

22. Enzel P, Bein T (1989) J Chem Soc Chem Commun 18:1326

23. Uehara H, Miyake M, Matsuda M, Sato M (1998) J Mater Chem 8:2133

24. Wu CG, Bein T (1994) Science 266:1013

25. Kageyama K, Tamazawa J, Aida T (1999) Science 285:2113

26. Lin VSY, Radu DR, Han MK, Deng W, Kuroki S, Shanks BH, Pruski M, (2002) J Am Chem Soc 124:9040

27. Cardin DJ, Constantine SP, Gilbert A, Lay AK, Alvaro M, Galletero MS, Garcia H, Marquez F (2001) J Am Chem Soc 1233141

28. Molenkamp WC, Watanabe M, Miyata H, Tolbert S (2004) J Am Chem Soc 126:4476

29. Sozzani P, Bracco S, Comotti A, Simonutti R, Valsesia P, Sakamoto Y, Terasaki O (2006) Nature Mater 5:545 
30. Moulton B, Zaworotko MJ (2001) Chem Rev 101:1629

31. Janiak C (2003) Dalton Trans 2781

32. Kitagawa S, Kitaura R, Noro SI (2004) Angew Chem Int Ed 43:2334

33. Ockwig NW, Delgado-Friedrichs O, O’Keefe M, Yaghi OM (2005) Acc Chem Res 38:176

34. Férey G, Mellot-Draznieks C, Serre C, Millange F (2005) Acc Chem Res 38:217

35. Bradshaw D, Claridge JB, Cussen EJ, Prior TJ, Rosseinsky MJ (2005) Acc Chem Res 38:273

36. Kepert CJ (2006) Chem Commun 695

37. Kitagawa S, Noro SI, Nakamura T (2006) Chem Commun 701

38. Forster PM, Cheetham AK (2003) Top Catal 24:79

39. Kesanli B, Lin W (2003) Coord Chem Rev 246:305

40. Wu CD, Hu A, Zhang L, Lin W (2005) J Am Chem Soc 127:8940

41. Wu CD, Lin W (2007) Angew Chem Int Ed 46:1075

42. Fujita M, Kwon YJ, Washizu S, Ogura K (1994) J Am Chem Soc 116:1151

43. Seo JS, Whang D, Lee H, Jun SI, Oh J, Jeon YJ, Kim K (2000) Nature 404:982

44. Pan L, Liu H, Lei X, Huang X, Olson DV, Turro NJ, Li J (2003) Angew Chem Int Ed 42:542

45. Cho SH, Ma B, Nguyen SBT, Hupp JT, Albrecht-Schmitt TE (2006) Chem Commun 2563

46. Dybtsev DN, Nuzhdin AL, Chun H, Bryliakov KP, Talsi EP, Fedin VP, Kim K (2006) Angew Chem Int Ed 45:916

47. Hasegawa S, Horike S, Matsuda R, Furukawa S, Kinoshita Y, Kitagawa S (2007) J Am Chem Soc 129:2607

48. Uemura T, Horike S, Kitagawa S (2006) Chem Asian J 1:36

49. Eddaoudi M, Kim J, Rosi N, Vodak D, Wachter J, O'Keefe M, Yaghi OM (2002) Science 295:469

50. Chui SSY, Lo SMF, Charmant JPH, Orpen AG, Williams ID (1999) Science 283:1148

51. Kitaura R, Kitagawa S, Kubota Y, Kobayashi TC, Kindo K, Mita Y, Matsuo A, Kobayashi M, Chang HC, Ozawa T, Suzuki M, Sakata M, Takata M (2002) Science 298:2358

52. Higuchi M, Horike S, Kitagawa S (2007) Supramol Chem 19:75

53. Chen BL, Ockwig NW, Millward AR, Contreras DS, Yaghi OM (2005) Angew Chem Int Ed $44: 4745$

54. Schlichte K, Kratzke T, Kaskel S (2004) Micropor Mesopor Mater 73:81

55. Kosal ME, Chou JH, Wilson SR, Suslick KS (2002) Nature Mater 1:118

56. Matsuda R, Kitaura R, Kitagawa S, Kubota Y, Belosludov RV, Kobayashi TC, Sakamoto H, Chiba T, Takata M, Kawazoe Y, Mita Y (2005) Nature 436:238

57. Shin DM, Lee IS, Chung YK (2003) Inorg Chem 42:8838

58. Uemura K, Matsuda R, Kitagawa S (2005) J Solid State Chem 178:2420

59. Bradshaw D, Warren J E, Rosseinsky MJ (2007) Science 315:977 
60. Serre C, Mellot-Draznieks C, Surblé S, Audebrand N, Filinchuk Y, Férey G (2007) Science 315:1828

61. Kitaura R, Seki K, Akiyama G, Kitagawa S (2003) Angew Chem Int Ed 42:428

62. Halder GJ, Kepert CJ, Moubaraki B, Murray KS, Cashion JD (2002) Science 298:1762

63. Moad G, Solomon DH (ed) (2006) The Chemistry of Radical Polymerization 2nd ed. Elsevier, Oxford

64. Matyjaszewski K, Davis TP (ed) (2002) Handbook of Radical Polymerization. WileyInterscience, Hoboken

65. Uemura T, Kitagawa K, Horike S, Kawamura T, Kitagawa S, Mizuno M, Endo K (2005) Chem Commun 5968

66. Uemura T, Ono Y, Kitagawa K, Kitagawa S (2008) Macromolecules 41:87

67. Uemura T, Hiramatsu D, Kubota Y, Takata M, Kitagawa S (2007) Angew Chem Int Ed 46:4987

68. Uemura T, Kitaura R, Ohta Y, Nagaoka M, Kitagawa S (2006) Angew Chem Int Ed 45:4112

69. Habaue S, Okamoto Y (2001) Chem Rec 1:46.

70. Kamigaito M, Sato K (2008) Macromolecules 41:269

71. Lutz JF, Neugebauer D, Matyjaszewski K (2003) J Am Chem Soc 125:6986

72. Lutz JF, Jakubowski WD, Matyjaszewski K (2004) Macromol Rapid Commun 25:486

73. Wan D, Satoh K, Kamigaito M, Okamoto Y (2005) Macromolecules 38:10397

74. Hirano T, Ishii S, Kitajima H, Seno M, Sato T (2005) J Polym Sci Part A Polym Chem 43:50

75. Maeda K, Goto H, Yashima E (2001) Macromolecules 34:1160

76. Nakako H, Nomura R, Tabata M, Masuda T (1999) Macromolcules 32:2861

77. Tabata M, Inaba Y, Yokota K, Nozaki Y (1994) J Macromol Sci Pure Appl Chem A31:465

78. Furlani A, Napoletano C, Russo MV, Feast WJ (1986) Polym Bull 16:311

79. Li Z, Day M, Ding JF, Faid K (2005) Macromolecules 38:2620

80. Koo JS, Smith PGR, Williams RB, Grossel MC, Whitcombe MJ (2002) Chem Mater 14:5030

81. Kamigaito K, Ando T, Sawamoto M (2001) Chem Rev 101:3689

82. Matyjaszewski K, Xia J (2001) Chem Rev 101:2921

83. Hawker CJ, (1997) Acc Chem Res 30:373

84. Wakioka M, Baek KY, Ando T, Kamigaito M, Sawamoto M (2002) Macromolecules 35:330

85. Iovu MC, Matyjaszewski K (2003) Macromolecules 36:9346

86. Simms RW, Davis TP, Cunningham MF (2005) Macromol Rapid Commun 26:592

87. Koumura K, Satoh K, Kamigaito M, Okamoto Y (2006) Macromolecules 39:4054

88. Debuigne A, Caille JR, Jérôme R (2005) Macromolecules 38:5452

89. Debuigne A, Caille JR, Detrembleur C, Jérôme R (2005) Angew Chem Int Ed 44:3439 


\section{Figures}

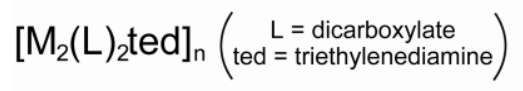

\begin{tabular}{ccc}
$\mathbf{M}$ & pore size $\left(\AA^{2}\right)$ \\
\hline $\mathrm{Cu}^{2+}$ & $10.8 \times 10.8$ \\
$\mathrm{Cu}^{2+}$ & $7.5 \times 7.5$
\end{tabular}

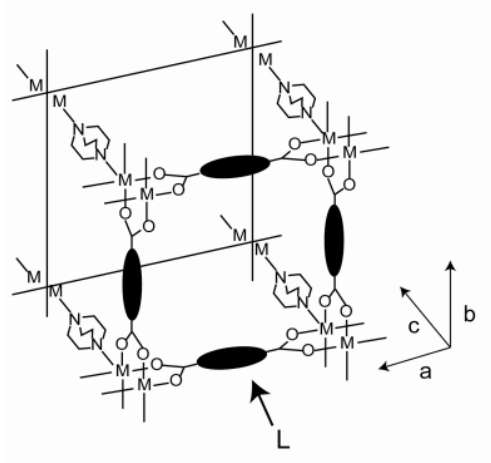

$\mathrm{Cu}^{2+}$

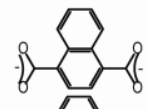

$5.7 \times 5.7$

$\mathrm{Cu}^{2+}$

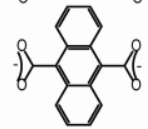

$4.8 \times 4.3$

$\mathrm{Zn}^{2+}$

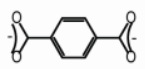

$7.5 \times 7.5$

$\mathrm{Zn}^{2+}$

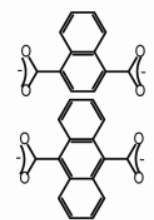

$5.7 \times 5.7$

$\mathrm{Zn}^{2+}$

Fig. 1 Schematic illustration of $\left[\mathrm{M}_{2}(\mathrm{~L})_{2} \text { ted }\right]_{\mathrm{n}}\left(\mathrm{M}=\mathrm{Cu}^{2+}\right.$ or $\left.\mathrm{Zn}^{2+}\right)$.

(a)

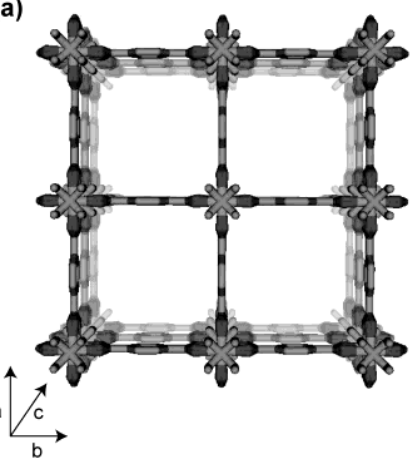

(b)

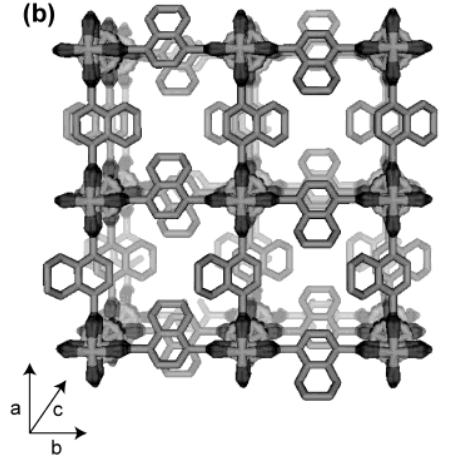

(c)

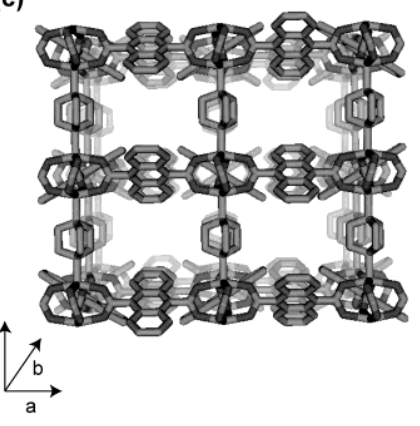

Fig. 2 Nanochannel structures of (a) $\left[\mathrm{Zn}_{2}(\mathrm{bdc})_{2} \mathrm{ted}\right]_{n}$, (b) $\left[\mathrm{Zn}_{2}(\mathrm{ndc})_{2} \mathrm{ted}\right]_{n}$, and (c) $\left[\mathrm{Zn}_{2}(\mathrm{adc})_{2} \text { ted }\right]_{n}$ displayed by stick model. Hydrogen atoms and disordering atoms in the phenylene planes are omitted for clarity. 


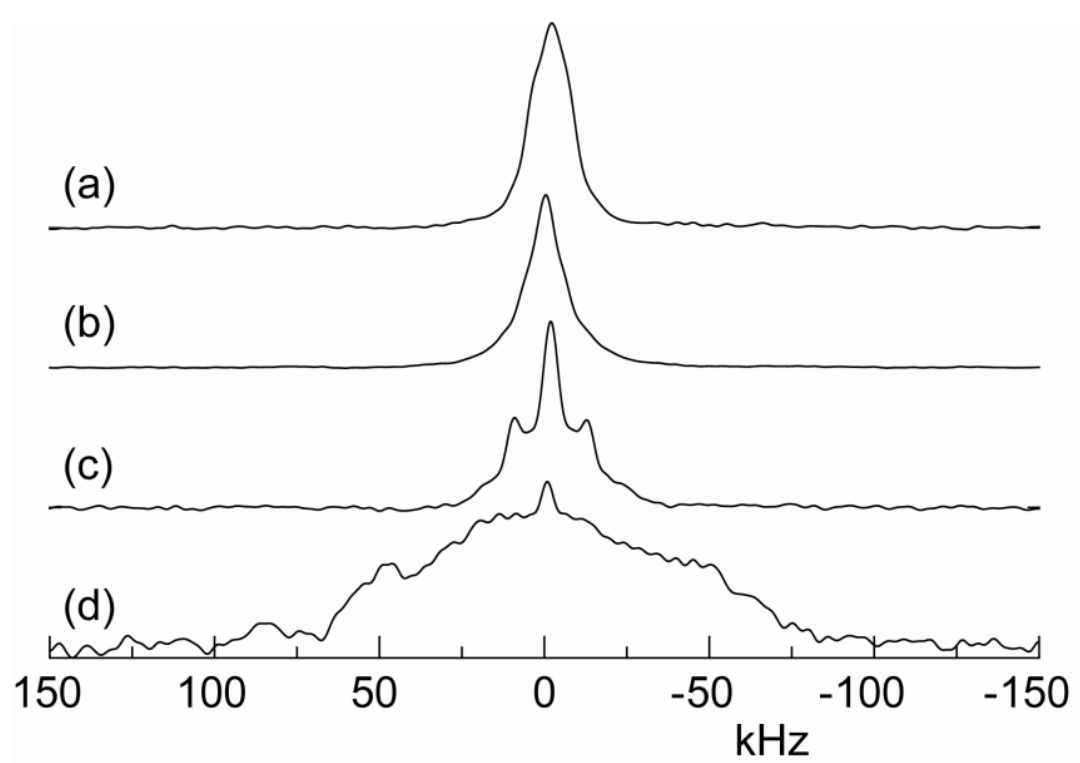

Fig. 3 Solid-state ${ }^{2} \mathrm{H}$ NMR spectra of St- $d_{8}$ adsorbed in the nanochhanels of (a) $\left[\mathrm{Cu}_{2}(\mathrm{bpd})_{2} \text { ted }\right]_{n}$, (b) $\left[\mathrm{Cu}_{2}(\mathrm{bdc})_{2} \text { ted }\right]_{n}$, (c) $\left[\mathrm{Cu}_{2}(\text { ndc })_{2} \text { ted }\right]_{n}$, and (d) $\left[\mathrm{Cu}_{2}(\mathrm{adc})_{2} \mathrm{ted}\right]_{n}$ at $70{ }^{\circ} \mathrm{C}$.
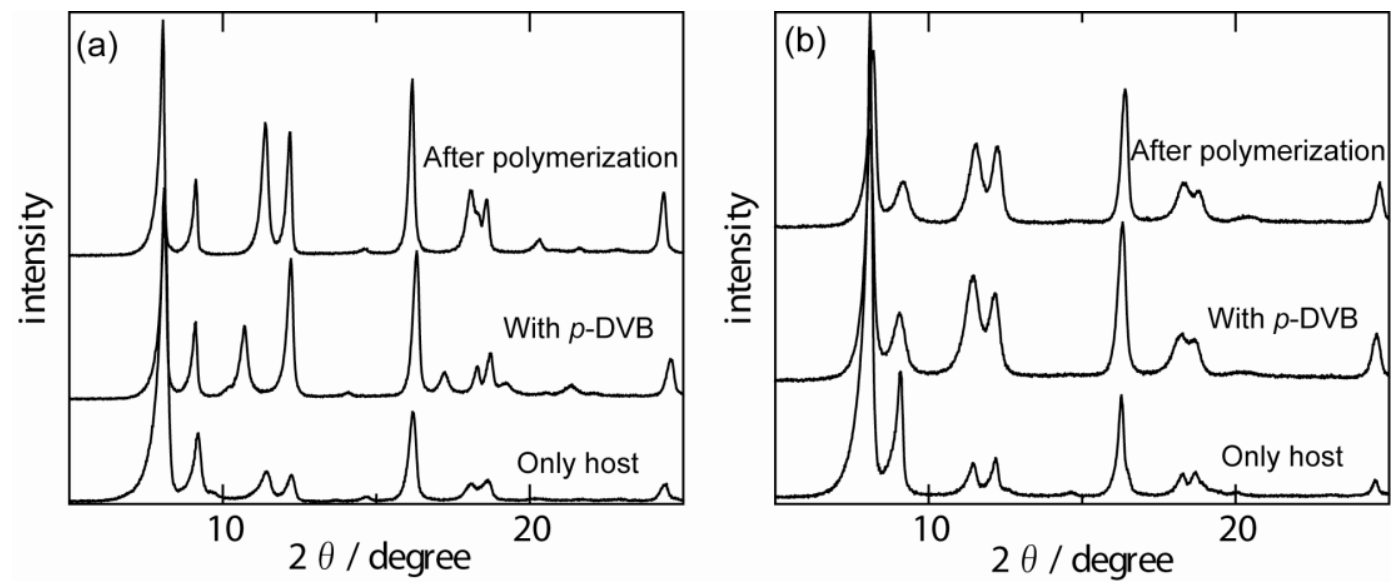

Fig. 4 XRPD patterns of (a) $\left[\mathrm{Zn}_{2}(\mathrm{bdc})_{2} \mathrm{ted}\right]_{n}$ and (b) $\left[\mathrm{Cu}_{2}(\mathrm{bdc})_{2} \text { ted }\right]_{n}$ during the polymerization of $p$-DVB monomer in the nanochannels. 
(a)

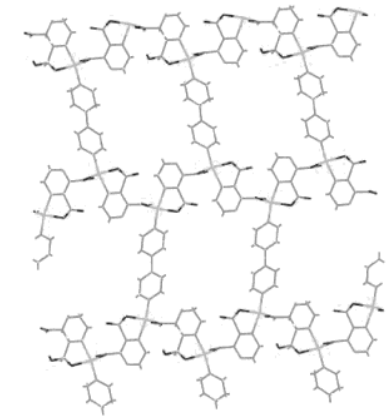

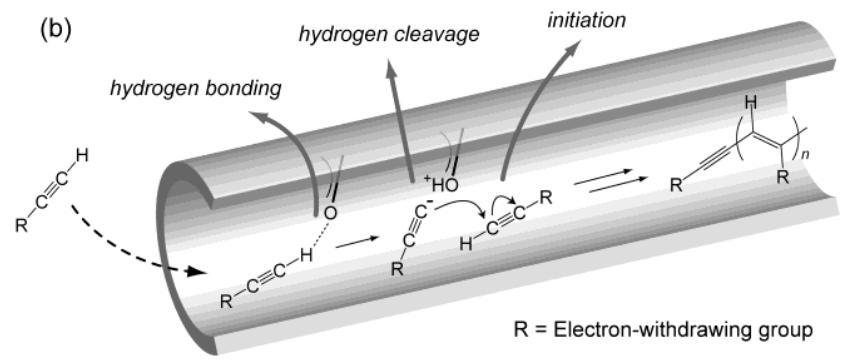

Fig. 5 (a) Nanochannel structure of $\left[\mathrm{Cu}_{2}(\mathrm{pzdc})_{2} \mathrm{bpy}\right]_{n}$. (b) Schematic illustration for nanochannel-promoted polymerization of acidic acetylenes in $\left[\mathrm{Cu}_{2}(\mathrm{pzdc})_{2} \mathrm{bpy}\right]_{n}$.
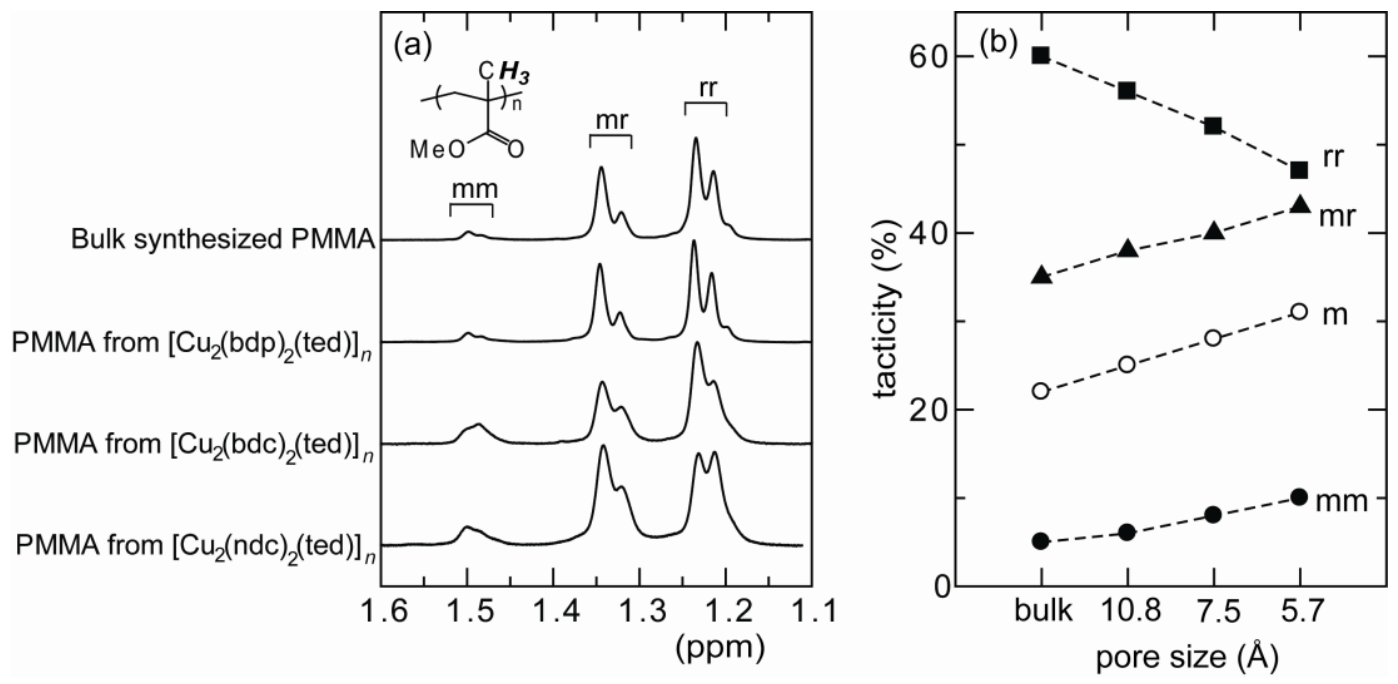

Fig. 6 (a) ${ }^{1} \mathrm{H}$ NMR spectra of PMMA obtained from the nanochannels of $\left[\mathrm{Cu}_{2}(\mathrm{~L})_{2}(\text { ted })\right]_{n}$ and the bulk condition in nitrobenzene- $d_{5}$ at $110{ }^{\circ} \mathrm{C}$. (b) Plot of nanochannel size effect on tacticity of PMMA. 

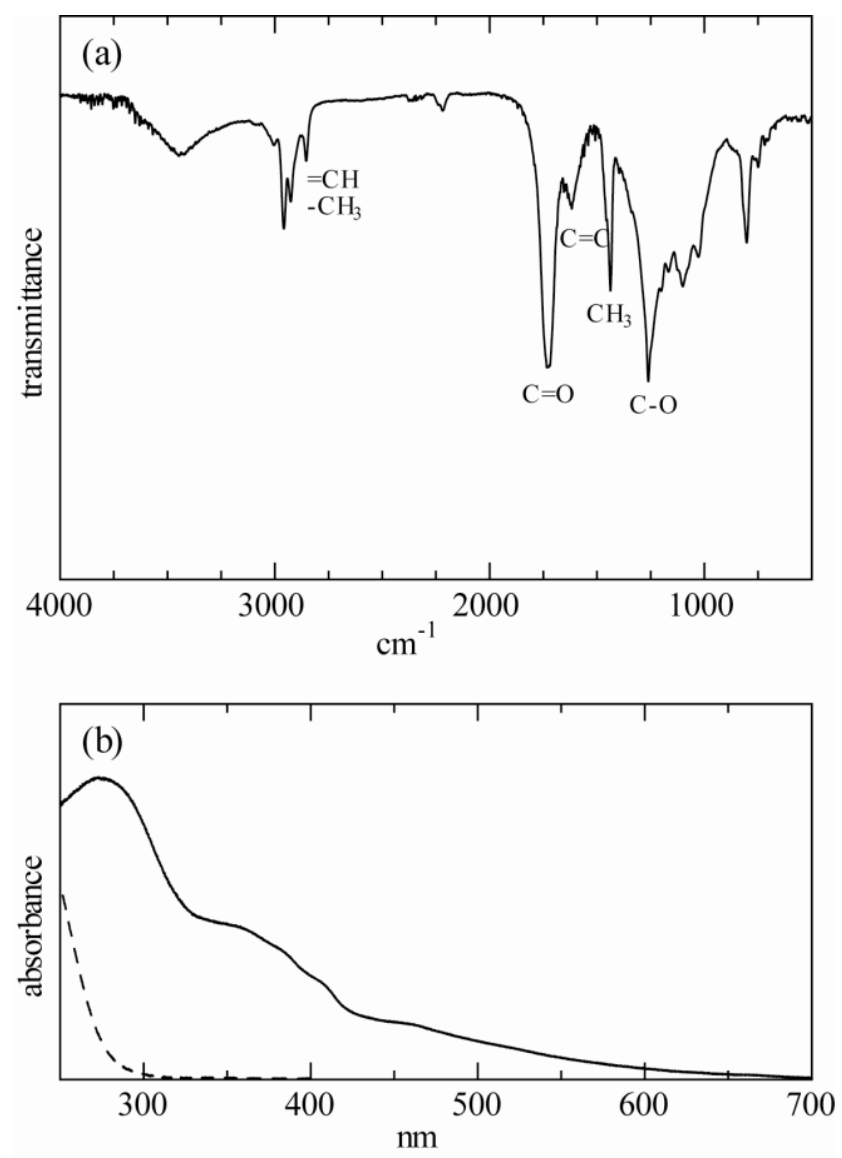

Fig. 7 (a) IR spectrum of poly(methyl propiolate) prepared in $\left[\mathrm{Cu}_{2}(\mathrm{pzdc})_{2} \mathrm{bpy}\right]_{n}$. The presence of a band at $970 \mathrm{~cm}^{-1}$ suggests that the trans-geometry is dominant in this polymer structure. (b) UV-vis absorption spectra of poly(methyl propiolate) prepared in $\left[\mathrm{Cu}_{2}(\mathrm{pzdc})_{2} \mathrm{bpy}\right]_{n}$ (solid line) and monomeric methyl propiolate (dot line) in chloroform. The appearance of a band at a longer wavelength $(>480 \mathrm{~nm})$ in the absorption spectrum of the polymer supports the highly conjugated trans form of poly(methyl propiolate).

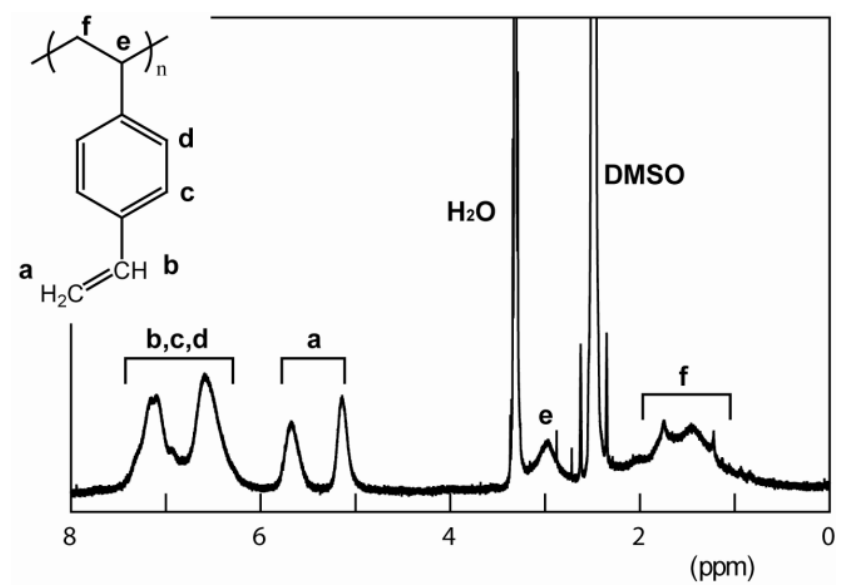

Fig. $8{ }^{1} \mathrm{H}$ NMR spectrum of poly( $p$-DVB) obtained from the nanochannel of $\left[\mathrm{Zn}_{2}(\mathrm{bdc})_{2} \mathrm{ted}\right]_{n}$ in DMSO- $d_{6}$. The ratio of the peak intensities of $\mathbf{a}$ to those of $\mathbf{b}, \mathbf{c}$, and $\mathbf{d}$ is found to be $2: 5$. 


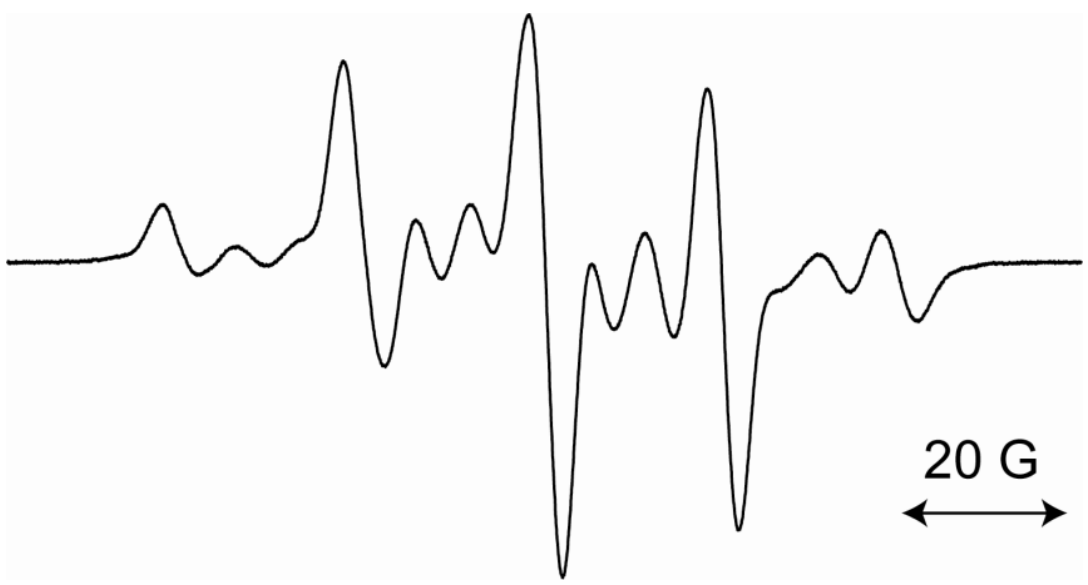

Fig. 9 ESR spectrum for propagating radical of PMMA in the nanochannel of $\left[\mathrm{Zn}_{2}(\mathrm{bdc})_{2}(\mathrm{ted})\right]_{n}$.

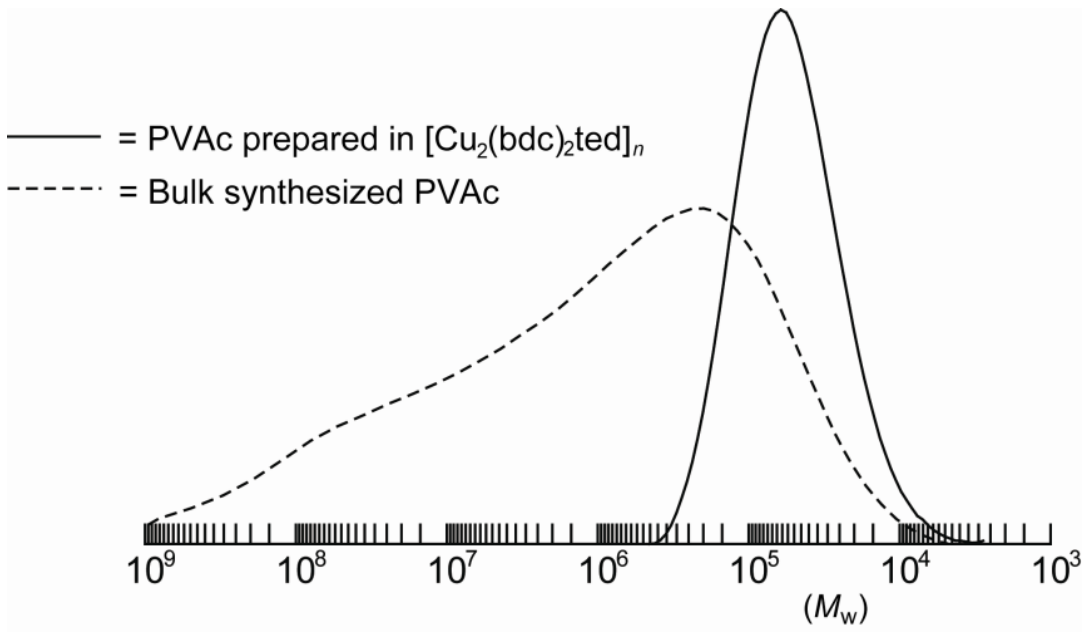

Fig. 10 GPC profiles of PVAc prepared in $\left[\mathrm{Cu}_{2}(\mathrm{bdc})_{2}(\text { ted })\right]_{n}$ and in the bulk condition. 
Table 1. Polymerization of St in Nanochannels of $\left[\mathrm{M}_{2}(\mathrm{~L})_{2}(\text { ted })\right]_{n}$ at $70{ }^{\circ} \mathrm{C}$ for $48 \mathrm{~h}$

\begin{tabular}{|c|c|c|c|c|}
\hline $\begin{array}{c}\text { Host } \\
\left.\text { (Pore size }\left[\AA^{2}\right]\right)\end{array}$ & $\begin{array}{c}\text { Adsorbed } \\
\text { monomer amount } \\
\text { (number/unit cell) }^{a}\end{array}$ & Conversion $(\%)^{a}$ & $M_{\mathrm{n}}\left(M_{\mathrm{w}} / M_{\mathrm{n}}\right)^{b}$ & $\begin{array}{c}\text { Tacticity }^{c} \\
\text { mm:mr:rr (m) }\end{array}$ \\
\hline $\begin{array}{c}{\left[\mathrm{Cu}_{2}(\mathrm{bpd})_{2}(\mathrm{ted})\right]_{n}} \\
(10.8 \times 10.8)\end{array}$ & 3.1 & 81 & $14,000(3.3)$ & 19:40:41 (39) \\
\hline $\begin{array}{l}{\left[\mathrm{Cu}_{2}(\mathrm{bdc})_{2}(\mathrm{ted})\right]_{n}} \\
\quad(7.5 \times 7.5)\end{array}$ & 2.5 & 71 & $54,600(1.6)$ & $19: 42: 39(40)$ \\
\hline $\begin{array}{l}{\left[\mathrm{Cu}_{2}(\mathrm{ndc})_{2}(\mathrm{ted})\right]_{n}} \\
\quad(5.7 \times 5.7)\end{array}$ & 2.2 & 58 & $10,100(1.6)$ & $19: 40: 41(39)$ \\
\hline $\begin{array}{l}{\left[\mathrm{Cu}_{2}(\mathrm{adc})_{2}(\mathrm{ted})\right]_{n}} \\
\quad(4.8 \times 4.3)\end{array}$ & 1.6 & 0 & - & - \\
\hline $\begin{array}{l}{\left[\mathrm{Zn}_{2}(\mathrm{bdc})_{2}(\mathrm{ted})\right]_{n}} \\
\quad(7.5 \times 7.5)\end{array}$ & 2.5 & 71 & $56,200(1.7)$ & $16: 43: 41(38)$ \\
\hline $\begin{array}{l}{\left[\mathrm{Zn}_{2}(\mathrm{ndc})_{2}(\mathrm{ted})\right]_{n}} \\
\quad(5.7 \times 5.7)\end{array}$ & 2.1 & 56 & $11,100(1.5)$ & $17: 42: 41(38)$ \\
\hline $\begin{array}{c}{\left[\mathrm{Zn}_{2}(\mathrm{adc})_{2}(\mathrm{ted})\right]_{n}} \\
\quad(4.8 \times 4.3)\end{array}$ & 1.6 & 0 & - & - \\
\hline Bulk polymerization $^{d}$ & - & - & $37,600(4.7)$ & $16: 42: 42(37)$ \\
\hline
\end{tabular}

Table 2. Polymerization of MMA in Nanochannels of $\left[\mathrm{M}_{2}(\mathrm{~L})_{2}(\text { ted })\right]_{n}$ at $70{ }^{\circ} \mathrm{C}$ for $7 \mathrm{~h}$

\begin{tabular}{|c|c|c|c|c|}
\hline $\begin{array}{c}\text { Host } \\
\text { (Pore size }\left[\AA^{2}\right] \text { ) }\end{array}$ & $\begin{array}{c}\text { Adsorbed } \\
\text { monomer amount } \\
\text { (number/unit cell) }^{a}\end{array}$ & Conversion $(\%)^{a}$ & $M_{\mathrm{n}}\left(M_{\mathrm{w}} / M_{\mathrm{n}}\right)^{b}$ & $\begin{array}{c}\text { Tacticity }^{c} \\
\text { mm:mr:rr (m) }\end{array}$ \\
\hline $\begin{array}{c}{\left[\mathrm{Cu}_{2}(\mathrm{bpd})_{2}(\mathrm{ted})\right]_{n}} \\
(10.8 \times 10.8)\end{array}$ & 3.2 & 76 & $93,000(4.8)$ & $6: 38: 56(25)$ \\
\hline $\begin{array}{c}{\left[\mathrm{Cu}_{2}(\mathrm{bdc})_{2}(\mathrm{ted})\right]_{n}} \\
\quad(7.5 \times 7.5)\end{array}$ & 2.6 & 74 & $73,100(2.0)$ & 8:40:52 (28) \\
\hline $\begin{array}{c}{\left[\mathrm{Cu}_{2}(\mathrm{ndc})_{2}(\mathrm{ted})\right]_{n}} \\
\quad(5.7 \times 5.7)\end{array}$ & 2.3 & 58 & $30,600(2.4)$ & $10: 43: 47(31)$ \\
\hline $\begin{array}{c}{\left[\mathrm{Cu}_{2}(\mathrm{adc})_{2}(\mathrm{ted})\right]_{n}} \\
(4.8 \times 4.3)\end{array}$ & 1.8 & 0 & - & - \\
\hline $\begin{array}{l}{\left[\mathrm{Zn}_{2}(\mathrm{bdc})_{2}(\mathrm{ted})\right]_{n}} \\
\quad(7.5 \times 7.5)\end{array}$ & 2.7 & 76 & $69,100(2.4)$ & $8: 40: 52(28)$ \\
\hline $\begin{array}{l}{\left[\mathrm{Zn}_{2}(\mathrm{ndc})_{2}(\mathrm{ted})\right]_{n}} \\
\quad(5.7 \times 5.7)\end{array}$ & 2.3 & 60 & $29,500(2.4)$ & $9: 41: 50(30)$ \\
\hline $\begin{array}{l}{\left[\mathrm{Zn}_{2}(\mathrm{adc})_{2}(\mathrm{ted})\right]_{n}} \\
\quad(4.8 \times 4.3)\end{array}$ & 1.8 & 0 & - & - \\
\hline Bulk polymerization $^{d}$ & - & - & $56,100(6.4)$ & $5: 35: 60(22)$ \\
\hline
\end{tabular}


Table 3. Polymerization of VAc in Nanochannels of $\left[\mathrm{M}_{2}(\mathrm{~L})_{2}(\text { ted })\right]_{n}$ at $60{ }^{\circ} \mathrm{C}$ for $48 \mathrm{~h}$

\begin{tabular}{|c|c|c|c|c|}
\hline $\begin{array}{c}\text { Host } \\
\left(\text { Pore size }\left[\AA^{2}\right]\right)\end{array}$ & $\begin{array}{c}\text { Adsorbed } \\
\text { monomer amount } \\
\text { (number/unit cell) }^{a}\end{array}$ & Conversion $(\%)^{a}$ & $M_{\mathrm{n}}\left(M_{\mathrm{w}} / M_{\mathrm{n}}\right)^{b}$ & $\begin{array}{c}\text { Tacticity }^{c} \\
\text { mm:mr:rr (m) }\end{array}$ \\
\hline $\begin{array}{c}{\left[\mathrm{Cu}_{2}(\mathrm{bpd})_{2}(\mathrm{ted})\right]_{n}} \\
(10.8 \times 10.8)\end{array}$ & 5.3 & 49 & $48,000(2.4)$ & $22: 49: 29(47)$ \\
\hline $\begin{array}{c}{\left[\mathrm{Cu}_{2}(\mathrm{bdc})_{2}(\mathrm{ted})\right]_{n}} \\
(7.5 \times 7.5)\end{array}$ & 3.3 & 47 & $41,500(1.7)$ & 29:50:21 (54) \\
\hline $\begin{array}{c}{\left[\mathrm{Cu}_{2}(\mathrm{ndc})_{2}(\mathrm{ted})\right]_{n}} \\
\quad(5.7 \times 5.7)\end{array}$ & 2.7 & 0 & - & - \\
\hline $\begin{array}{c}{\left[\mathrm{Cu}_{2}(\mathrm{adc})_{2}(\mathrm{ted})\right]_{n}} \\
\quad(4.8 \times 4.3)\end{array}$ & 1.9 & 0 & - & - \\
\hline $\begin{array}{l}{\left[\mathrm{Zn}_{2}(\mathrm{bdc})_{2}(\mathrm{ted})\right]_{n}} \\
\quad(7.5 \times 7.5)\end{array}$ & 3.4 & 66 & $36,000(2.0)$ & $30: 49: 21(55)$ \\
\hline $\begin{array}{c}{\left[\mathrm{Zn}_{2}(\mathrm{ndc})_{2}(\mathrm{ted})\right]_{n}} \\
\quad(5.7 \times 5.7)\end{array}$ & 2.6 & 0 & - & - \\
\hline $\begin{array}{c}{\left[\mathrm{Zn}_{2}(\mathrm{adc})_{2}(\mathrm{ted})\right]_{n}} \\
\quad(4.8 \times 4.3)\end{array}$ & 1.8 & 0 & - & - \\
\hline Bulk polymerization $^{d}$ & - & - & n.d. ${ }^{e}$ & $22: 50: 28(47)$ \\
\hline \multicolumn{5}{|c|}{$\begin{array}{l}{ }^{a} \text { Determined by TGA. }{ }^{b} \text { Obtained by GPC calibrated by PMMA standards. }{ }^{c} \text { Determined by }{ }^{13} \mathrm{C} \text { NMF } \\
\text { measurement in DMSO- } d_{6} \text { at } 100{ }^{\circ} \mathrm{C} \text { after conversion to poly(vinyl alcohol) by saponification. }{ }_{d}^{d} \text { Bull } \\
\text { polymerization was carried out under a comparable condition to those employed in PCPs. }{ }^{e} \text { The obtainec } \\
\text { polymer had high molecular weight portions over exclusion limit }\left(M_{\mathrm{w}}>5,000,000\right) \text { of GPC column witl } \\
\text { extremely wide polydispersity }\left(M_{\mathrm{w}} / M_{\mathrm{n}}>20\right) \text {. }\end{array}$} \\
\hline
\end{tabular}




\section{Graphic Abstract}

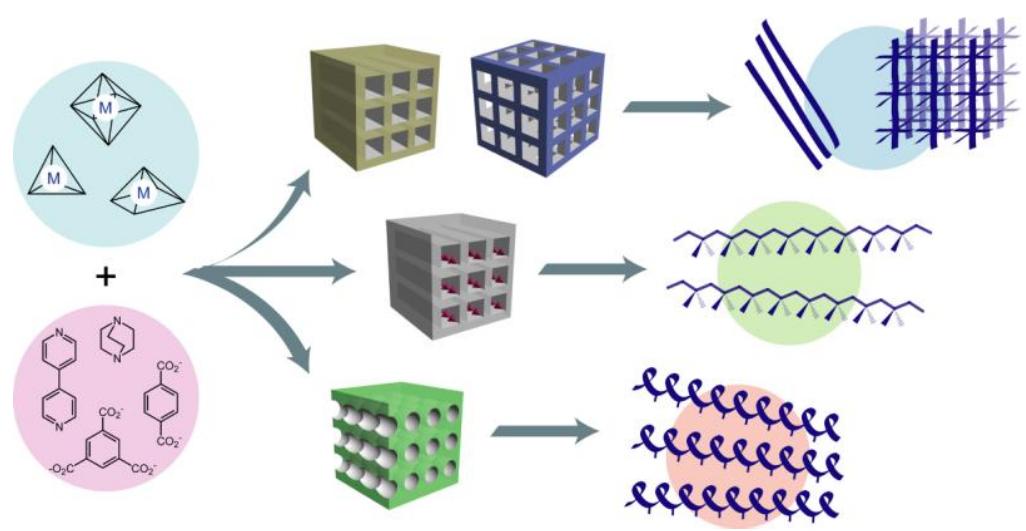

